\title{
15. \\ SMRT GRAĐANSKE ELITE \\ U ZIMSKOM LJETOVANJU
}

\section{Svetlana Šeatović}

UDK: 821.163.42-311.1Desnica, V.:316.42“194“

Prethodno priopćenje

Sažetak: U radu je analiziran kulturološki i poetički aspekt smrti odnosno skoro potpunog nestanka iz Dalmacije etničkih Italijana, pripadnika srednje i više građanske klase, u Desničinom romanu Zimsko ljetovanje (1950) i, komparativno, u romanu Dalmacijo stara Dalmacijo (1979) Ivana Katušića. Motiv smrti, ratne opasnosti i neposrednog ratnog okruženja predstavljaju istorijske okolnosti Drugog svetskog rata u Zadru, njegovom zaleđu, i u drugim dalmatinskim gradovima. Prva seoba građanskog stanovništva pod velom preteće smrti predstavlja pomeranje u zaleđe, koje predstavlja drugu, ruralnu sredinu. Strah od smrti u građanima iz Zadra podstiče složena antropološka, kulturološka i verska pitanja. Analizom likova pojedinih građana i seljaka ukazuje se na susret i sukob različitih kultura i civilizacija. Smrt će za građane Zadra biti dvostrukog karaktera - prvo seoba i potom konačno iseljavanje. Zimsko ljetovanje najavljuje, mada sa skepsom, klasni prevrat, koji će biti osnova novog socijalističkog uređenja na prostorima Jugoslavije, pa će rad ukazati i na smenu društvenih uređenja koja će se odvijati tokom Drugog svetskog rata i konačan epilog dobiti upravo krajem rata. ${ }^{1}$

Ključne reči: egzil, kontrapunkt, identitet, mentalitet, društvene promene, građanska klasa, urbano, ruralno

[3 opusu Vladana Desnice Dalmacija je sveprisutna zemlja dvojnosti. S jedne strane more i gradovi, Zadar i Split, a sa druge zaleđe, imaginarni Smiljevci, Zagora, rodni Islam Grčki. Nijedan pisac sa prostora Dalmacije nije u modernom periodu bolje razumeo, tumačio i umetnički izatkao antipodnu sliku ovoga regiona. Vladan Desnica je to mogao svojim svestranim obrazovanjem, životnim iskustvom čoveka koji je poreklom iz zaleđa, odrastao u Zadru i Splitu, poznavanjem mentaliteta Vlaja, srpskog i hrvatskog stanovništva u Zagori, ali i visokog građanstva slovenskog i romanskog porekla u urbanim sredinama Zadra i Splita. Zimsko ljetovanje je i taj oksimoronski spoj dvojne Dalmacije, paradoksalnih i bizarnih situacija u kojima su život i smrt dva lica jednog prostora i vremena. Malo

1 Rad je nastao u okviru naučnog projekta Smena poetičkih paradigmi u srpskoj knjževnosti 20. veka-nacionalni i evropski kontekst (178016) Instituta za književnost i umetnost, koji finansira Ministarstvo prosvete, nauke i tehnološkog razvoja Republike Srbije. 
bi koji antropolog bolje od Desnice - u njegovom eseju o Mirku Koroliji - opisao taj svet, geoistorijski i mentalitetski:

Dalmacija u svojoj cjelini obuhvata i sjedinjuje razna područja koja se, pod djelovanjem posebnih prirodnih uslova i različitih istorijskih udesa, među sobom dosta oštro razlikuju. U toj zemlji gdje raste i oleandar i grab; gdje uz obalu u maistralu leprša dašak romanskog duha i vije se laka zapadna melopeja, a po zaleđu u buri struji duboko rasni narodni život i gudi primitivni monokord; gdje uz katedrale sa Ticijanima i Veronezima postoje i manastiri u kojima tinja duh srednjevjekovne srpske manastirske obrazovanosti, u kojima caruju krute bizantinske ikone i u kojima se čuvaju zavjeti Nemanjića; gdje pored primorskog trubadura nalazimo i mrgodnog brđanskog kaluđera ljetopisca - u toj zemlji, među raznovrsnim osobitostima koje je uslovila priroda i stvorila istorija, i sjevernodalmatinski kopneni kraj, naseljen izbjeglicama koji su se od 15 . vijeka dalje sklanjali pred Turcima na njegov goli krš i sure visoravni, predstavlja, po svojim specijalnim kulturnim, psihičkim i ekonomskim momentima, jedno izdvojeno područje. ${ }^{2}$

Desnica u eseju o Mirku Koroliji obrazlaže koliko je narod koji je doseljen na taj sirov i primitivan kršs, sa svojom narodom epikom, jednostavno zalutao u latinsko primorje, obeleženo duhovnim uticajem zapadne kulture i politike. U takvom sudaru stanovništva u zaleđu Zadra i građana, neminovan je razdor, zjap koji nastaje već na vratima grada. $\mathrm{Na}$ takvoj liniji se susreću likovi Zimskog ljetovanja iz seoskog ambijenta sa stanovnicima Zadra građanskog i romanskog porekla u jesen 1943. i zimu 1944. godine. Egzil italijanskog građanskog stanovništva iz Splita, u romanu Dalmacijo stara Dalmacijo Ivana Katušića, predstavlja temu veoma blisku Zimskom ljetovanju, ali sa preciznijom slikom i razumevanjem seoskog stanovništva sa pozicije građana. Delimično razumevanje između likova memoarskog romana Ivana Katušića Dalmacijo stara Dalmacijo nalazimo u komunikaciji šjor Bepa, romanskog predstavnika visoke srednje klase Splita, sa stanovnicima sela u Zagori. Šjor Bepo je junak koji ume da prilagodi čak i jezički izraz, prilikom komunikacije sa seljankama od kojih kupuje višnje, ali i da njegov sin Turiddu pomogne pri oslobađanju Marinog sina iz zatvora u Splitu. Svest o pripadanju visokoj građanskoj klasi obrazovanjem, materijalnim statusom, kulturološkim nasleđem ima upravo šjor Bepo Ivaneo. Gospar Ivaneo ume da percipira drugu stranu, koju čine Vlaji, znajući da kultura i obrazovanje nisu u te krajeve stigli voljom njegovih stanovnika, već političkim odlukama vladara.

Likovi Zimskog ljetovanja, koji su predstavnici nižeg građanskog sloja Zadra, nemaju tako široko obrazovanje ni sposobnost da tumače ruralnu stranu iza gradskih vrata. Desničini junaci Zimskog ljetovanja, kao niža građanska klasa, ne znaju sve istorijske razloge koji su njihove domaćine u Smiljevcima doveli na tako nizak civilizacijski nivo. Najistaknutiji lik, šjor Karlo, jednom je bio u pokrajini Alto Adiđe, kod brata poštara, i to je među Desničinim likovima najviši domet saznanja o svetu „preko mora“. Možemo samo da pretpostavimo da je Desnica svesno izabrao baš niži sloj građana, jer bi viša klasa verovatno razumela smiljevačke stanovnike, a sigurno ne bi ni čekala u zaleđu, već bi odmah krenula na drugu stranu Jadrana. Vladan Desnica u eseju o Koroliji može da tumači zaostalost jer je i sam bio predstavnik više građanske klase najšireg obrazovanja:

2 Vladan Desnica, „Mirko Korolija i njegov kraj“, Eseji, članci, pogledi, Beograd 1993., 29. 
Tuđinske vladavine držale su smišljenim programom ovaj živalj u kulturnoj zaostalosti i svim sredstvima ugušivale svaki njegov napor za kulturnim pridizanjem. (...) I kobne posljedice zaostalosti i nerazvijenosti pokazuju se jasno još i danas na psihi tog naroda. Odatle, kao glavna negativna strana, ono jako izraženo nedostajanje duhovnosti i poriva na viši razmah. (...) Dok je nedostajala svaka disciplina duha, razvila se je prirođena bistrina uma i izoštrilo ničim nezamagljeno uočavanje i spoznavanje realnog. Tako se je skorjela ona toliko karakteristična određenost jednog naziranja na svijet, praktičnog, duboko i neumitno materijalističkog. ${ }^{3}$

Zimsko ljetovanje, kao realistički roman, predstavlja izuzetan primer kontapunktnog odnosa dva sveta, dve civilizacije, ruralnog i urbanog, verskih antipoda pravoslavnih seljaka i građana katolika. Do sada je dosta pisano i o sukobu ideoloških tokova u vreme Drugog svetskog rata, koji se odslikavaju u pozadini romana - istovremeni tok četničkog pokreta, partizana i, sa druge strane, fašističkih predstavnika, italijanske vlasti - $\mathrm{u}$ formi reminiscencija kroz epizodu sa Milom Plačidrugom - i aktuelne nemačke okupacione vlasti, koja je preuzela prostor posle kapitulacije Italije u jesen 1943. godine. Uprkos svim dvojstvima na kojima je konstruisana kompozicija i semantika romana, iz te celine možemo sagledati opštiji pogled na Dalmaciju sa zaleđem, koja je mesto smenjivanja vladara, ideologija, naroda. Na tu najdublju istorijsku strukturu Dalmacije ukazuje Ernesto, prilikom polaganja zakletve četničkom vojvodi Duletu. Posle položene zakletve izbeglice iz Zadra smatrale su da je logično, da je to njihova obaveza - jer su ipak dobili azil u zaleđu grada - da se pokore prvoj vlasti koja to od njih zatraži. Međutim, Ernesto posle zakletve jednostavnim iskazom ukazuje na istorijsku kompleksnost Dalmacije: „Jesmo se mi Dalmatinci nazaklinjali kao niko drugi! Ali da ćemo i ovu zakletvu morati da damo, to, bogami, niko ne bi mogao predvidjeti!“4

Apsurd u polaganju četničke zakletve, kao vrhunac kontrapunkta zadarskih izbeglica i ruralnog zaleđa, predstavlja odluka građana da, posle tako neočekivanog gesta u Žagrovcu, svrate u lokalnu krčmu i razvesele se uz jagnjeće pečenje i vino. Tu vrstu odluke, koju je inicirao upravo Ernesto, vidimo kao oblik katarzičkog doživljaja celokupne situacije topla jagnjetina sa ražnja i vino zbrisaće sve besmislice ljudi građanskog sloja, uglavnom romanskog porekla i katoličke vere. Dakle, apsurd je bio potpun, kao i oksimoron kojim je šjor Karlo njihov boravak na selu nazvao „zimsko ljetovanje“. Boravak građana u Smiljevcima predstavlja, dakle, oblik egzotičnog putovanja; on će, dok traje lepo vreme, imati odlike avanture, a kada stignu kiše i sumorno vreme, oko katoličkog Božića i Nove godine, izbeglicama iz Zadra doneće tugu i gorčinu. Zbog toga njihov položaj možemo imenovati pozicijom „emigranata“ i „egzota“, kako ovaj termin uvodi Cvetan Todorov. ${ }^{5}$ Prisilno izgnanstvo ili emigrantstvo, egzil, doživljavaju se kao egzotično putovanje, čime se anesteziraju prvi utisci i doživljaji realnog stanja.

Vraćajući se sa četničke zakletve, noću, u Smiljevce, šjor Karlo, kao junak filozofskih opservacija, izvrsno opisuje kako je i boravak na selu u ratno vreme dovoljan da čovek do-

Isto, 30-31.

$4 \quad$ Vladan Desnica, Zimsko ljetovanje, Beograd 1993., 129.

5 Videti: Cvetan Todorov, Mi i drugi. Francuska misao o ljudskoj raznolikosti, Beograd 1994., 332-333. 
živi svetska i neverovatna čuda. Svako mesto na svetu je teatar u malom pa zbog toga i šjor Karlo, koji je obrazovan, koji je čak video italijansku pokrajinu Alto Adiđe, zaključuje:

Razlagao je kako nam se život, i pored njegove prividne jednoličnosti, ako se samo malo dublje i pozornije razmotri, pokazuje u stvari vrlo složen, pun neočekivanog i, ukoliko samo nije tragičan, vrlo zanimljiv. Da stoga, na koncu konca, čovjek može da doživi u Smiljevcima ili u Žagrovcu neke čudne i neobjašnjive stvari i da dođe u svakojake situacije, ne manje nego u San Francisku ili u Jokohami. ${ }^{6}$

Teritorijalna, verska i nacionalna razlika građana iz Zadra i seljaka iz Smiljevaca veoma je slikovito predstavljena i iskazom šjor Karlovog prijatelja Pompe Bauka, koji nije hteo da napusti grad iako je on već sav u ruševinama, obrazlažući svoju odluku ovako:

(...) tu sam se rodio i tu hoću i da umrem. A osim toga, bojim se da me tamo, u Morlakiji,

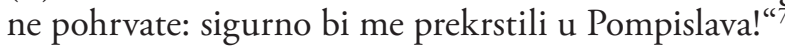

Dakle, prethodno usađene predstave stanovnika Zadra o narodu u zaleđu i u najgorim egzistencijanim trenucima izazivaju stereotipne predstave obeležene međusobnim nepoverenjem:

Susreti među kulturama otpočinju od nulte tačke, od tabula rasae. Gotovo svaki susret je - uglavnom nesvesno - određen i ranijim kontaktima ili istorijskim iskustvom sa drugom kulturom, sačuvanim u kolektivnom pamćenju. Gotovo svaki kulturni kontakt stoga je određen i sopstvenim ili prenesenim iskustvom koje je ostavilo konkretan trag ili dobilo izraz u specifičnim predstavama o drugom. ${ }^{8}$

Desnica tek ovlašno provlači, kroz glas pripovedača ili izveštaje likova izbeglica, da ljudi iz Zadra odlaze i „preko mora“, i tako posredno saznajemo za dobrovoljni egzil brojnih stanovnika koji napuštaju grad emigrirajući u Italiju. Reč je svakako o građanskom srednjem i višem sloju stanovništva romanskog porekla, koji su želeli da napuste Zadar izložen stalnom bombardovanju, mesto na kome posle kapitulacije Italije nisu videli nikakvu perspektivu. Tako Desnica iz centralnog odnosa stanovnika Smiljevaca i izbeglica iz Zadra razvija i posredne tokove, koji ukazuju na složenu situaciju u jeku Drugog svetskog rata. Tome doprinosi i posredna informacija, koja stiže do smiljevačkih izbeglica, da je čak i porodica Vidošević otišla u Italiju, a ona sasvim sigurno nije samo romanskog porekla.

Ićanova grupa izbeglica, na čelu sa Ernestom, planirala je takođe odlazak u Italiju jer u Zadru nisu videli mogućnosti za nastavak života. Iz toga se isključuje samo šjor Karlo sa Anitom. On otvoreno kazuje da je njima ostalo još malo godina, i da u nekim godinama nema smisla odlaziti „preko mora“. Osim egzistencijalnh razloga i veoma diskretno nagoveštenih smena društvenih uređenja, nalazimo i starosni faktor kao odlučujuću okolnost koja likove dovodi u poziciju prve seobe ili trajnog iseljenja u Italiju. Tako se u Smiljevcima oko Nove godine donose odluke o egzilu građana koji su se nadali povratku u Zadar, da bi

\footnotetext{
V. Desnica, Zimsko ljetovanje, 130-131.

7 Isto, 152.

8 Klaus Rot, Slike u glavama. Ogledi o narodnoj kulturi u jugoistočnoj Evropi, Beograd 2000., 270.
} 
tokom jeseni i zime shvatili da je odlazak preko mora jedino rešenje. Tada se gube njihovi egzotični doživljaji prve seobe, da bi se, potom, brzo transformisali u tugu, žaljenje na teške uslove života, vlagu, na stalne priče o „udaranju krmka“ i, na kraju, u bizarnu naturalističku scenu u kojoj svinja Migud jede malu Špižmicu. Na taj način se, i direktno, junaci Zimskog ljetovanja uvode u izbeglička putešestvija, koja se neće završiti u Smiljevcima, već se taj put nastavlja u pravcu Italije (mada će se za neke od njih završiti upravo tragičnim krajem devojčice Špižmice).

Prvo iseljenje iz Zadra građana srednje i niže klase romanskog porekla odvija se pod okolnostima neposrednog bombardovanja, i predstvalja za sve njih samo privremeno rešenje. Međutim, druga seoba, i konačan egzil, mnogo je kompleksnija odluka, koja je posledica ratnih okolnosti, ekonomskih prilika i postojanja tri različita vojna tabora. $\mathrm{Na}$ jednoj strani su, posle italijanskih fašista, u zaleđu nemački vojnici, ali se istovremeno smenjuju i četnički i partizanski odredi. U tako složenoj vojnoj i ideološkoj situaciji, gde jedno selo ili njegova okolina polažu zakletve, gde mladi ljudi odlaze u šumu da bi se priključili partizanskom pokretu dok Nemci pokušavaju da kontrolišu celo to područje - za građane iz Zadra italijanskog porekla tu nema mesta. I tu počinje sasvim izvesna „simbolička smrt“ niže građanske klase u Zadru i zaleđu.

Na drugoj liniji je antipodna situacija između grada Zadra i Zagore; to je vekovni sukob više i niže civilizacije, mešavine kultura, Morlakije, Vlaja i građana Zadra. Taj sukob stvorio je odnos dubokog nepoverenja - antropološku podelu u kojoj nema mogućnosti za razumevanje jer su razlike jezičke, mentalitetske, verske i duboko civilizacijske.

Jovan Cvijić u studiji Psibičke osobine Južnih Slovena razdvaja jadranski i zagorski varijetet na prostoru Dalmacije. Jadranski varijetet predstavljaju doseljenici iz dinarskih krajeva i staro romansko stanovništvo, ali u gradovima duž obale Jadrana. Zagorsku grupu čine doseljenici koji su ostali u krševitim područjima, gde žive u zadrugama tj. porodičnim grupama koje broje i do 80 članova. Odnos stanovništva u zaleđu i predstavnika gradova, pa čak i ostrva, Cvijić opisuje i kroz njihov humor i nadimke, koji nose i jezičke i karakterne osobine. Tako možemo razumeti brojne nadimke i lokalna imenovanja seljaka u Smiljevcima. Cvijić kaže:

Često se u Zagori naiđe na mentalitet, naročito na duh i humor, varijeteta Ere. Porodični nadimci su kod njih češći nego po drugim dinarskim oblastima. Svi, i žene i ljudi, pa čak i deca, imaju nadimke kojima se ukazuje više na njihove moralne ili umne nego na telesne osobine. Uživaju da učine smešnim Bodule, stanovnike jadranskih ostrva, ali im ovi odvraćaju nazivajući ih Vlasima ili Morlacima.

Vladan Desnica, odgovarajući u tekstu „O jednom gradu i o jednoj knjizi“ na brojne negativne kritike i tekst Jože Horvata, podseća na kontekst: istoriju grada Zadra, mentalitet i odnos urbanog stanovništva i naroda koji je živeo u zaleđu grada. Podstaknut, dakle, veoma oštrim kritičkim tekstovima, Desnica prikazuje složene istorijske, političke, ideološke i kulturološke odnose u Zadru, odmah ukazujući budućim čitaocima i tumačima ovoga

9 Jovan Cvijıć, Psihičke osobine Južnih Slovena, Beograd 2006., 127. 
romana da je realistički postupak samo prividan, a da se najkomplikovaniji sudari različitih svetova nalaze u pozadini osnovnog pripovedačkog toka obeleženog kontrastima i oksimoronskim spojevima. Zimsko ljetovanje prevazilazi tu osnovnu liniju sudara urbanog i ruralnog, građanskog ${ }^{10}$ sveta i seoske sredine, koji se odvija i kroz ideološke i mentalitetske razlike, a potom otkriva i u diskretno nagoveštenom egzodusu građana italijanskog porekla. Zadar je, za Desnicu, grad u kome su se vekovima smenjivale tuđinske vlasti, ali napominje da to pitanje nije rešeno ni 1918. godine. U Drugom svetskom ratu Zadar će, kao malo ostrvo pod italijanskom kontrolom, ostati izolovana zona, koja će epilog doživeti posle kapitulacije Italije 1943. godine, što će se najbolje ispoljiti u odlukama izbeglica romanskog porekla tokom jeseni i zime u Smiljevcima. Desnica zatim, kao izuzetan poznavalac prilika u Zadru i zaleđu, obrazlaže posledice formiranja zadarske enklave:

(...) u Rapallu Zadar biva dodijeljen Italiji i pada u posljednje, i možda najteže, svoje sužanjstvo - četvrtstoljetno sužanjstvo Italiji i fašizmu - da najzad tek godine 1944. bude konačno oslobođen i prisajedinjen svojoj pravoj majci zemlji. (...) U novije vrijeme, favoriziran političkom linijom Austro-Ugarske monarhije, koja je podržavala anemičnu i njoj neopasnu talijansku manjinu kao utuk i protutežu slavenskoj većini, taj službeni, birokratski Zadar dosta je brzo asimilirao ne samo dio seoskog življa, koji je neprekidno u nj priticao, nego i onaj činovnički i vojno-činovnički element, koji je Austrija tu dovodila iz svojih gornjih krajeva na više upravne položaje i na skromna činovnička zvanja. Pa, čak i donedavna, za talijanske dominacije između dva svjetska rata, taj birokratski otuđeni Zadar uspijevao je da k sebi privuče i smota po kojeg sirovog sina iz kulturno-zaostalog zaleđa - pokojeg Milu Plačidruga. ${ }^{11}$

U okviru naše teme, koja prati kontrastni odnos ruralnog stanovništva i egzil italijanskih građanskih porodica u Zadru, komparativno nalazimo, i veoma precizno i umetnički kompleksno opisanu sudbinu porodice Ivaneo iz Splita, u romanu Ivana Katušića Dalmacijo stara Dalmacijo. Pozicije Zadra i Splita nisu istovetne, ali je egzil italijanskog građanstva veoma sličnog karaktera. Ivan Katušić se u svom memoarskom romanu usmerava na poziciju porodice italijanskog porekla u Dalmaciji između dva rata, i na njihov dobrovoljni egzodus 1943, prilikom kapitulacije Italije, ali mnogo eksplicitnije i sa manje umetničkih i estetskih postupaka ukazuje na dvojstvo dva sveta. Desničini stavovi o poziciji Zadra u tome periodu veoma su dragocen izvor za razumevanje istorijske, kulturološke i antropološke opozicije selo - grad. Mada je Split bio sasvim drugačije organizovan, posle Rapalskog sporazuma, pozicija italijanske manjine i širi građanski odnos prema zaleđu vrlo su slični onima u Zadru, s tom razlikom što je u Zadru građanska elita bila na još višem nivou, pa je odnos prema Morlakiji bio samo zaoštreniji. Desnica ističe da se upravo u Zadru razvila izuzetna građanska sredina, nažalost zatvorena u sebe i odvojena od svoga zaleđa. Ipak, treba imati u vidu da je takva građanska sredina, ma-

\footnotetext{
10 Videti: Vladimir Rismondo, „Roman Zimsko ljetovanje Vladana Desnice u svjetlu kulturalnih studija“, Split i Vladan Desnica 1918. - 1945.: umjetničko stvaralaštvo između kulture i politike. Zbornik radova sa znanstvenog skupa Desničini susreti 2015. (ur. Drago Roksandić i Ivana Cvijović Javorina), Zagreb 2016., 131-143. Rismondo u navedenom radu ističe odnos "narodnjaštva“ $i$,talijanštva“ kao jedan od osnovnih kulturnih i civilizacijskih oblika u kojima se sudaraju nasleđa likova iz zaleđa i građanskog stanovnišstva.

11 Vladan Desnica, „O jednom gradu i o jednoj knjizi“, Eseji, članci, pogledi, Beograd 1993.,114-115.
} 
da je predstavljala - kako kaže Desnica - „steriliziran prostor“, bila veoma podsticajna u kulturološkom razvoju. Desnica posebno naglašava koliko je daleko otišao taj građanski svet Zadra:

Po toj urbanosti Zadar ne samo da je predstavljao nesumnjivo najgradskiji i najgrađanskiji ambijent kod nas, nego je pripadao valjda među najgrađanskije ambijente evropskog $\mathrm{Za}$ pada. ${ }^{12}$

Do sada je u novijoj literaturi bilo nekoliko novih pogleda na sliku drugog, koja se najbolje razume imagološkim studijama. Davor Dukić u radu „Nekoliko imagoloških opaski o Zimskom ljetovanju i Desničinim susretima“ pruža osnovne pravce u kojima bi se ovaj roman mogao tumačiti kao dobar primer za imagološke studije. U veoma precizno definisanim okvirima Dukić pravi selekciju imagoloških elemenata u Desničinom romanu:

(...) Vladan Desnica je građanski elitist i kozmoplit koji prezire identifikacije ispod razine svjetonazorskog (filozofskog) - etničko, jezično i konfesionalno za njega je akcidentalno i kao takvo ga zapravo ne zanima. To ne znači da pojam identiteta nije operabilan u analizi semantike njegovih djela, kao uostalom i bilo kojeg drugog modernog zapadnog proznog opusa. Rijeć je samo o jednom od onih autora koji tradicionalno shvaćanje kolektivnog identiteta demistificira, ironizira, razgrađuje. Riječima teorije književne semantike Gaje Peleša, u Desničinom romanu psihemsko, a naročito ontemsko važniji su od sociemskog. ${ }^{13}$

Sa ovoga aspekta možemo se složiti sa dosadašnjom selekcijom imagoloških nivoa koje je dao Davor Dukić, na osnovu najbolje literature savremene imagologije. Veoma je značajan Dukićev stav da je psihološki i ontološki status likova značajniji od socioekonomskog, i tu je pravi put na kome se mogu definisati razlike građanskog sloja Zadra u susretu sa seoskim imaginarnim selom Smiljevci. Dubina njihovog razdora nije samo u različitosti ekonomskih i socijalnih slojeva kojima pripadaju, već je ona u psihologiji i mnogo složenijoj antropologiji čoveka zaleđa Dalmacije. Likovi Zimskog ljetovanja iz seoske sredine nisu svesni te antropološke odlike koja je određena istorijskim okolnostima poslednjih 500 godina, oni su prosto određeni svojim naslednim načelima junačkog, herojskog kulta, koji potiče iz narodnog stvaralaštva, jedinog dostupnog izvora saznanja o sopstvu, vremenu i prostoru na kome se obitava. Uza sve to, vremenom su se razvile stereotipne predstave o građanima, koje se neće nikada promeniti, kao što ni građani nikada neće imati poverenja u seosko stanovništvo. Prema već citiranom Klausu Rotu, naše predstave uvek su posledica iskustava i prethodno usađenih saznanja. Posle svega, dakle, između jednih i drugih ostaje samo zid nepoverenja. Samo će šjor Bepo, u Katušićevom romanu Dalmacijo stara Dalmacijo, imati tu vrstu svesti o svome i složenom identitetu Morlakije, ali je za takvo poimanje bila potrebna visoka srednja građanska klasa vanrednog obrazovanja. Zbog toga smo i odabrali ovaj roman, u kome je moguće da junak razume i sebe i drugoga. U Zim-

\footnotetext{
V. Desnica, Zimsko ljetovanje, 116.

13 Davor Dukić, „Nekoliko imagoloških opaski o Zimskom ljetovanju i Desničinim susretima“, Desničini susreti 2005. - 2008. Zbornik radova (ur. Drago Roksandić i Ivana Cvijović Javorina), Zagreb 2010., 155.
} 
skom ljetovanju to nije moguće zbog stereotipnih predstava i nivoa obrazovanja izbeglica iz Zadra. Zoran Kravar u Desničinom romanu vidi te nasleđene stereotipe, i oštru liniju razdvajanja bez mogućnosti samorazumevanja, i zbog toga kaže:

Napokon, u Zimskom ljetovanju na istom se prostoru susreću, zadržavajući naslijeđene stereotipe jedne o drugima, građani i seljaci, ljudi podijeljeni civilizacijskom demarkacijom koja u južnoslavenskim književnostima rijetko ostaje bez ideološke nadinterpretacije, bilo da se pisac, poput Miroslava Krleže u Povratku Filipa Latinovicza ili Milana Begovića u Gigi Barićevoj, oprezno priklanja modernističkom kozmopolitizmu, ili da ostaje na poziciji konzervativnoga ruralizma, poput većine hrvatskih i srpskih realista, ali i niza pisaca iz međuratnoga razdoblja, podjednako onih iz krugova „naprednjačke“ socijalne književnosti i onih okupljenih oko seljačkih i nacionalnih ideologija. U geokulturnom i povijesnom kontekstu koji okružuje tematiku Zimskoga ljetovanja ideologije su, dakle, bile i prisutne i djelotvorne. Kao subliminalne motivacije ili kao deklarirani programi pokretale su milijune ljudi, odlučivale o sadašnjosti i budućnosti velikih političkih sistema, gospodarile životom i smrću. Usprkos tome, Desničin je roman prema toj gigantomahiji ideoloških opcija ostao rezerviran, pozabavivši se diskurzivnom praksom koju danas prepoznajemo kao ideološku samo u usputnim epizodama. ${ }^{14}$

Dakle, neke od novijih analiza idu u pravcu definisanja imagoloških aspekata ili tragaju za ideološkom osnovom koja se pojavljuje samo u pojedinim usputnim epizodama. Tako, posle više od pedeset godina od objavljivanja romana Zimsko ljetovanje, vidimo da su oštre osude Jože Horvata i niz kritika oslonjenih na ideološku osnovu bile samo odjek jednog vremena, kada nije bilo korektno pisati o divljim i surovim egzekucijama mladih partizanskih četa u selima Dalmacije. Naprotiv, danas se jasno vidi da je ta vrsta recepcije bila upravo u ulozi ideologije socijalizma, da je Desničin pripovedački postupak bio usmeren na dvojstvo Dalmacije, koje je mnogo starije od modernih političkih ideologija 19. i 20. veka. Zbog toga možemo danas govoriti o smrti građanske elite, koja nije bila isključivo ideološkog karaktera, već je taj egzil srednjeg i visokog sloja građanskog stanovništva Zadra i Splita bio posledica i identitetskih pripadnosti. Šjor Bepo u Katušićevom romanu, kao antifašista i veletrgovac čija porodica već vekovima živi u Splitu, napušta taj grad sa koferom kostiju svojih predaka i dragim stvarima, 1943. godine, spremajući se za odlazak i pre kapitulacije Italije. Kao predstavnik italijanske manjine jasno zaključuje u kome smeru ide njegov život i život njegovih predaka, čije kosti nosi u koferu. Ipak, mesto koje je odabrao za preseljenje predaka određeno je i putevima drugih izbeglica iz Evrope koje su građanskog porekla, i u seobu polaze iz ideoloških razloga:

Ukratko, već sam kupio grob u Veneciji, na otoku svetog Mihovila... U neposrednom susjedstvu naše grobne parcele - jedan prognani madžarski grof, zatim nepoznati operski pjevač iz Beča i još jedan anonimni pokojnik, kojemu po imenu i prezimenu ne možeš odrediti nacionalnost... Ispada kao da sam se upisao u legiju stranaca (...) ja nemam ništa zajedničko s Mussolinijem, ali on za mene gubi rat... On ga za mene nije mogao dobiti, jer njegova pobjeda nije moja pobjeda, a njegov poraz je i moj poraz. ${ }^{15}$

\footnotetext{
14 Zoran Kravar, „Zimsko ljetovanje Vladana Desnice pod ideološkokritičkim lećama“, Desničini susreti 2010. Zbornik radova (ur. Drago Roksandić i Ivana Cvijović Javorina), Zagreb 2011., 12.

15 Ivan Katušić, Dalmacijo stara Dalmacijo, Split 1979., 291.
} 
Šjor Bepo upisuje svoje pretke i sebe u „legiju stranaca“ $\mathrm{i}$ - iako nije fašista - odlazi jer nije birao Musolinija, ali njegov poraz, kao predstavnika svih Italijana, poraz je i porodice Ivaneo, mada ni na koji način nije učestvovala u ratu.

Komparativnim pogledom na Katušićev roman, mnogo manjih estetskih dometa ali veoma bliske teme - egzila građanskog stanovništva iz Dalmacije, pre svega Zadra i Splita - nalazimo bliske veze sa najdubljim razlozima i namerama Vladana Desnice kada je pisao roman Zimsko ljetovanje. Tu su ideološki razlozi za iseljenje, pa ekonomski, ali pre svega to je pitanje nacionalnog identiteta te dve Dalmacije, latinske i urbane sa jedne strane, a sa druge - slovenske i ruralne. U Katušićevom romanu nalazimo i eksplicitno iznetu sliku o Dalmaciji koju su činili izmešani narodi slovenskog i romanskog porekla, ali je ideologija fašizma postavila nepremostive razlike, i delimično osudila čak i nevine antifašiste italijanskog porekla. Zbog toga će Bepo Ivaneo, i njegov sin Turiddu, koji se još u Rimu priključio komunističkom pokretu, ipak napustiti Split, na iznenađenje njihovog prijatelja Prošpe, auktorijalnog pripovedača romana Dalmacijo stara Dalmacijo.

Desničini junaci nisu spremni da vode ovako složene razgovore o istoriji Dalmacije, smeni ideoloških sistema - njihov pogled dopire samo do sopstvenih malih zanatlijskih radnji i višeg higijensko-sanitarnog oblika života od junaka Smiljevaca i okoline. U Zimskom ljetovanju je odluka o odlasku preko mora više ekonomskog karaktera. To su izbeglice koje su se našle u mutnim vremenima, gde nije jasno kada će prestati savezničko bombardovanje Zadra, a još manje ko će tu vladati. Uprkos saznanju da je Italija kapitulirala, stanovnici Zadra spremaju se za egzil i prijavljuju na liste koje ih vode na brodove što idu na drugu stranu Jadrana. Nigde nema ni reči o učešću u fašističkom pokretu u Zadru bilo kog izbeglice u Smiljevcima, tako da njihova namera da krenu u drugu i konačnu seobu predstavlja samo pokušaj da se sklone u zemlju kojoj pripadaju identitetom, a ne ideološkim opredeljenjem, bežeći tako od komunizma. U Katušićevom romanu i šjor Bepo će potvrditi upravo takav stav, samo sa mnogo više političke i identitetske svesti:

(...) gdje se nalazi Ivaneo - tu je i Italija! Ali poslije crnih skvadrista, kvesturina, karabinjera i Svetog Roka, poslije bičeva i ricinusa - ja više ne mogu ostati na ovoj obali Jadrana. Cijeli Split, cijela Dalmacija znade da Bepo Ivaneo nije bio fašista, ali bih ipak do kraja života morao tumačiti zašto nisam bio fašista, kad su toliki drugi dalmatinski Talijani nosili crne košulje; morao bih pričati kako su crne košulje za mene od samog početka bile znak žalosti! A možda bi bilo najgore, što bi dobrodušna priznanja pojedinaca nosila u sebi blagi okus samilosti. ${ }^{16}$

U Katušićevom romanu nalazimo i Marka, oficira Kraljevine Jugoslavije, koga šjor Bepo štiti, skriva ga na svom imanju izvan Splita, i kada porodica Ivaneo napušta grad, u firmi ostaje ovaj vojnik prethodne države. Markova odluka da ostane u Splitu istovremeno je izbor čoveka koji nije hteo da se pridruži četničkom pokretu a nije mogao da pogazi zakletvu koju je dao kralju, tako da nije bilo ni reči o pristupanju partizanima. Major Marko u Katušićevom romanu kazuje tešku istinu ljudi koji su po sredini, neopredeljenih i odanih sta- 
roj ideji. Svoju sudbinu major definiše jednostavnim iskazom: „ja sam krhotina potonulog broda, krhotina na valovima “. ${ }^{17}$ Sin Bepa Ivanea želi da se, na kraju romana, pre konačnog egzila, pridruži dalmatinskim partizanima jer smatra da je Dalmacija njegov zavičaj, iako se godinama školovao u gimnaziji u Zadru, kao italijanskoj teritoriji, i potom studirao u Rimu. Ipak, osećaj pripadništva Dalmaciji i bliskost s idejama komunizma upućuju ga na ovakav čin. Otac Bepo Ivaneo oštro se protivi toj odluci, ali ne zbog ideoloških razloga, već zbog najsloženijeg saznanja da sa novom Jugoslavijom i stvaranjem novog, jugoslovenskog naroda - Dalmacija nestaje. Taj dijalog oca i sina u Splitu, u trenutku kapitulacije Italije, ideološko je i identitetsko pitanje. Sin Turiddu Ivaneo u dijalogu sa ocem, svesnim svih političkih i viševekovnih naslaga kulture i mentaliteta, odražava stvarno pitanje italijanske manjine koja će napustiti Dalmaciju:

- Želim da postanem Turiddus Dalmaticus - odgovorio je moj prijatelj nakon kratkog razmišljanja. - Dalmaticus? - nasmijao se šjor Bepo, prisilno, gorko. - Nema više Dalmaticus - postoji samo Jugoslavus... - Umjesto Jugoslavus, bolje bi bilo reći: Slavus meridionalis... (...) Doći ćeš u brigadu, imat ćeš crvenu zvijezdu na kapi, ali ćeš im svejedno, morati dokazivati da nisi bio fašista, ni ti ni tvoj otac...18

Tako se u razgovoru oca i sina otkrivaju pravi razlozi zbog kojih nije moguće ostati u Dalmaciji - jer nje više nema, ona je sada projekat komunističke Jugoslavije. Dalmacije nije nestalo u Kraljevini Jugoslaviji jer je kapitalističko uređenje ipak ostavilo stare odnose građanskih klasa, dok nova promena ideološkog tipa sad menja sve konture jednog geografskog, istorijskog, kulturološkog i antropološkog prostora određenog mešavinom naroda. To geografsko i klimatsko dvojstvo sada se potencira, i u njemu više nema mesta za građanstvo. Upravo tako izgleda smrt građanske klase na prostoru Dalmacije, i to posebno onih predstavnika koji su romanskog porekla.

Sudbina takvih porodica dvostruko je uslovljena. Šjor Bepo će sina podsetiti na zavet nona Tona, koji im je ostavio u amanet da moraju biti uz Italiju i kada propada, i zato otac pita sina: „Smijemo li mi napustiti Italiju u ovom trenutku kad je ona na rubu propasti?"19 U memoarskom romanu Dalmacijo stara Dalmacijo kao da progovara Vladan Desnica iz eseja, i sa porodičnim iskustvom predstavnika visoke građanske klase. Sudbina italijanske porodice Ivaneo određena je koliko ideološkim promenama, u kojima oni nisu ni na koji način učestvovali, toliko i osećanjem nacionalne pripadnosti matici zemlji. Tako se preko porodica koje su vekovima živele na jednom prostoru, a identitetski pripadale drugom, manjinskom narodu, prelamaju smene ideoloških sistema.

Katičić je glavnom junaku romana šjor Bepu pružio mogućnost da se jezički slojevito diferencira, pa on govori i kao vlaške seljanke: oponaša njihovu mimiku, gestikulaciju, logiku života, i u potpunosti razume onog drugog predstavnika niže klase i drugog identitetskog porekla. U Desničinom romanu likovi iz grada ni posle nekoliko meseci provedenih na selu, u Smiljevcima, ne mogu jezički da se sporazumevaju sasvim jasno, a logika i isto-

\footnotetext{
7 Isto, 300.

18 Isto, 303-305.

19 Isto, 305.
} 
rijsko nasleđe za njih su apsolutna nepoznanica. Kao što je i sam Desnica kazao - da je u Zimskom ljetovanju pokušao da pokaže fizionomiju grada i sela, kontrapunktnost njihovih mentaliteta i odnos prema osnovnim životnim pojavama, tako možemo videti da je druga seoba zadarskih izbeglica uslovljena ekonomskim, identitetskim i ideološkim razlozima. Katušićev roman Dalmacijo stara Dalmacijo nam, sa manje oštrine, prikazuje dvojstvo Dalmacije - ukazuje se viši stepen u razumevanju drugih, ali nam pruža i kompleksniju umetničku sliku sudbine italijanske porodice visokog građanskog sloja, koja je svesna svih podela i nužnog egzila kao jedinog oblika opstanka. Smrt građanske klase, i one niže u Zimskom ljetovanju i više u Katušićevom romanu, svedoči nam o surovosti istorijskih procesa u kojima pojedinac, bez obzira na ekonomski status, postaje žrtva već pripadanjem određenom narodu i društvenom položaju.

Drugi svetski rat je u Dalmaciji izmenio i strukturu stanovništva i društveno uređenje sa kojim je stigao novi svet, sa drugim vizijama kulture i razvoja. Zimsko ljetovanje je, osim realističkog pripovedanja, dalo i sliku tihe seobe, sa kojom je nestao jedan svet koji je na prostorima Dalmacije živeo vekovima.

\section{$\cos$}

\section{Literatura}

Jovan Cvijić, Psihičke osobine Južnih Slovena, Beograd 2006.

Vladan Desnica, „Mirko Korolija i njegov kraj“, Eseji, članci, pogledi, Beograd 1993., 29-48.

Vladan Desnica, „O jednom gradu i o jednoj knjizi“, Eseji, članci, pogledi, Beograd 1993., 112_ 127.

Vladan Desnica, Zimsko ljetovanje, Beograd 1993.

Davor Dukıć, „Nekoliko imagoloških opaski o Zimskom ljetovanju i Desničinim susretima“, Desničini susreti 2005. - 2008. Zbornik radova (ur. Drago Roksandić i Ivana Cvijović Javorina), Zagreb 2010., 149-156.

Ivan Katušić, Dalmacijo stara Dalmacijo, Split 1979.

Zoran Kravar, „Zimsko ljetovanje Vladana Desnice pod ideološkokritičkim lećama“, Desničini susreti 2010. Zbornik radova (ur. Drago Roksandić i Ivana Cvijović Javorina), Zagreb 2011., 9-17.

Vladimir Rismondo, „Roman Zimsko ljetovanje Vladana Desnice u svjetlu kulturalnih studija“, Split i Vladan Desnica 1918. - 1945.: umjetničko stvaralaštvo izmedu kulture i politike. Zbornik radova sa znanstvenog skupa Desničini susreti 2015. (ur. Drago Roksandić i Ivana Cvijović Javorina), Zagreb 2016., 131-143.

Klaus Rot, Slike u glavama. Ogledi o narodnoj kulturi u jugoistočnoj Evropi, Beograd 2000.

Cvetan Todorov, Mi i drugi. Francuska misao o ljudskoj raznolikosti, Beograd 1994. 


\section{$\cos$}

\section{The DEATH OF THE BOURGEOIS ELITE IN THE NOVEL ZIMSKO LJETOVANJE}

The paper analyses the cultural and social aspects of the metaphorical death, or more specifically the exile, of middle and upper-middle-class ethnic Italians from Dalmlatia, as depicted in Vladan Desnica's 1950 novel Zimsko ljetovanje (Summer vacations in winter) and Ivan Katušić's 1979 novel Dalmacijo, stara Dalmacijo (Dalmatia, old Dalmatia). The motifs of death, the threat of war and its immediate circumstances reflect the events of the Second World War in Zadar, its hinterland and other Dalmatian cities. Drawing from anthropological, historical and geographical interpretations, we have highlighted the many differences between the urban population of Zadar and the rural population of its hinterland. The refugees from Zadar who arrive in Smiljevci belong to the lower middle class and their stereotypical attitudes towards the Morlachs and Maurovlachia are the first source of misunderstanding between the two groups. The first migration of the urban population, caused by the fear of death, represents an encroachment on the hinterland, which is the other, rural environment. The fear of death raises complicated anthropological, cultural and religious issues for the citizens of Zadar. For them, death is twofold, coming first in the form of the move to Smiljevci and then later, because of economic downturn and imminent social changes, in the form of the eventual exile to Italy. The analysis of Katušić's novel Dalmacijo, stara Dalmacijo, with its protagonist, šjor Bepo Ivane, shows the upper class of the Italian bourgeoisie as having a much better understanding both of its own identity and the rural population of the hinterland. Zimsko ljetovanje foreshadows class revolt, which formed the basis for the new socialist system on the territory of the Yugoslavia. Katušić's novel, however, depicts the divide at the heart of Dalmatia as less insurmountable and paints a more complex picture of the fate of a former haute-bourgeois family, aware of social divisions and the inevitability of exile for survival. The death of the bourgeoisie, the lower middle class in Zimsko ljetovanje and the upper middle class in Dalmacijo, stara Dalmacijo alike, indicates the implacability of history, which can make victims out of individuals regardless of their wealth, for the mere fact of belonging to an ethnicity or a social class. World War II changed the structure of the population in Dalmatia, as well as the social system, precipitating the emergence of a new world, with different visions of culture and progress.

Key words: exile, counterpoint, identity, mentality, social change, the bourgeoisie, urban, rural 